\title{
What are the Costs and Benefits of a International Corporate Governance Reregulation?
}

\section{Francesco Di Tommaso}

\author{
Ph.D, Economics and Finance, University of Rome La Sapienza, Economics Faculty, Italy
}

\begin{abstract}
This work is a research that applies the organizational model of the business organization of Corporate Governance, to a process of changing in the organizational structure. This Paper defines the various organizational solutions and the various levels of complexity that the Corporate Governance structure, through its reference context, the load of available information and objectives, must support by choosing the optimal organizational solution. Before 2005 Enron under the management of American Government with a logic of mass production not very attentive to the different needs of customers. Today the optimal organizational solution adopted is the "perfect integration with its distributors" throughout the peninsula, maximizing the quality of service to the customer and the knowledge of the various areas of expertise making the company more flexible and more competitive. The growing generalized attention (businesses, investors, academic circles) towards of the Internal Control system is part of a complex evolutionary process characterized from: greater competition / boost to efficiency; emphasis on information transparency; innovative regulatory evolution.
\end{abstract}

The importance of the theme of Corporate Governance in the world is further increased thanks to the drafting of the international Corporate Governance Code for listed companies, which aims to reassure the community of international investors on the existence, in listed companies, of an organizational model which provides for adequate allocation of responsibilities and powers, and a correct one balance between management and control.

Keywords: corporate governance, financial markets.

JEL Classification: O16, G1.

(C) The Author, 2018. This article is published with open access at Sumy State University.

\section{Introduction}

\section{What is Corporate Governance?}

Corporate governance has become a familiar and increasingly popular term in Italy and in the World. With the introduction of the 1999 Law on Enterprises, the role of the private sector in economic development and job creation in United States began to accelerate. e following decade brought increasingly sophisticated domestic production, private enterprise growth and increased global competition. e downside to these developments has been the occurrence of major corporate scandals. While various domestic and international e companies have made corporate governance a household name, where few Italian companies appear to truly appreciate the depth and complexity of this topic. Indeed, corporate governance reforms are introduced superficially and used as a public relations exercise, rather than as a tool to introduce the internal structures and processes that enable a company to hold the trust of its shareholders, increase the company's ability to access capital and reduce vulnerability to financial crises. But to successfully introduce these structures and processes, a company must fully and continually commit to the principles of fairness, transparency, accountability and responsibility. This Paper defines corporate governance, makes a business case for its implementation, and provides an overview of the legal, regulatory and institutional frameworks for corporate governance in in Italy and an International Market today. The Purpose of the paper is to define the American corporate governance is generically translated into Italian with "corporate governance" referring to companies with shares listed on stock exchanges or other regulated markets. It is an elliptical expression to indicate the system of rules according to which companies are managed and controlled. It is the result of rules, traditions, behaviors developed by the individual economic and juridical systems and is certainly not due to a single model, exportable and practicable in all legal systems. All this includes legal provisions, statutory provisions, jurisprudential decisions as well as customary principles and business ethics. Not all the rules taken into consideration, therefore, are mandatory Alrabba, (Alrabba H. M. 2016). On the contrary, one of the objectives of the Italian debate on corporate governance is the delegation with the strengthening of the organizational autonomy of the societies and the downsizing of the space traditionally occupied by imperative rules. The 
corporate governance formula appears to the somewhat vague jurist; but this is precisely the reason for its success: it has inspired, in fact, projects for the reform of companies with widespread shareholding, which have recently led to the TUF. The news contained in the TUF regarding the protection of minority shareholders; reform of the powers of the board of statutory auditors and of the regulations of the shareholders' meeting; transparency of ownership structures in companies listed on the stock exchange or appealing to public savings, are directly inspired, in fact, to the principles of corporate governance developed in international practice. The structure of the corporate bodies, understood in its broader meaning and including the powers, functions, obligations and responsibilities of the members of the bodies is the central element of the debate. Rules of corporate governance are contained in the Corporate Governance Code prepared in 1999 by the Corporate Governance Committee of listed companies according to the best practice of the other European Union countries and of the US financial markets. It contains rules concerning the board of directors; chairman of the board of directors; board of statutory auditors; relationships between shareholders, especially among controlling shareholders and institutional investors. It also proposes the establishment of a series of committees whose task is to deal respectively with proposals for the appointment of the members of the board of directors and the remuneration of the members of the board; to perform an internal control function on the correct functioning of the corporate body (see also: Report on Corporate Governance (Indonesia Corporate Governance Manual-2014)).

2. Globalization, Global financial crisis of 2008-09 and Europe's Sovereign Debt Crisis of 2010. We are living in a highly "globalized and integrated world economy", continued liberalization of international trade is certain to further internationalize consumption patterns around the world and consumption, production of good and services has become highly globalized. To a Large extent, this has happened as a result of Multinational Financial Corporations' (MFNCs) relentless efforts to source inputs and locate production anywhere in the world where costs are lower and profits are higher. Recently, financial markets have also become highly integrated. This development allows investors to diversify their investment portfolios internationally. In 2009, for instance, U.S. investors collectively invested \$549 billion in foreign securities, such a stocks and bonds whereas foreigners invested $\$ 377$ billion $\mathrm{n}$ U.S. securities. Undoubtedly, we are now living in a word were all the major economic functions-consumption, production and investment are highly globalized. Although, the subprime mortgage crisis in the United States that began in the summer 2007 led to a severe credit crunch, making borrowing and refinancing difficult for households, firms and banks. The credit crunch, in turn, escalated to a full- blown global financial crisis in 2008-2009. The defending moment of the crisis came on September 14, 2008, when Lehman Brothers, a major U.S. investment bank, with a global presence, went bankrupt. The abrupt failure of an iconic U.S. bank touched off a major crisis of confidence in financial markets and institutions around the world. The crisis engulfed not only advanced economies, such as United States, Japan and the European Union but also many emerging economies, including Brazil, China and Russia. The world was sliding into the "Great Recession", the most serious, synchronized economic downturn since the Great Depression. Recently, however the euro's emergence as a global currency was death a serious set - back in the midst of Europe's sovereign debt crisis. The crisis started in December 2009 when the New Greek government revealed hat its budget deficit for the year would be 12.7 percent of the GDP, not the 3.7 percent previously forecast. The previous government had falsified the national account data. Unbeknownst to the outside the world, Greece was in a serious violation of Europe's stability pact, which limits the annual budget deficit of a euro-zone country to a maximum of 3 percent of GDP. This news surprised financial markets and prompted investors, who became worried about sovereign default, to sell off Greek government bonds. The sovereign debt crisis in Greece, which accounts for only about 2.5 percent of eurozone GDP, quickly escalated to a Europe-wide debt crisis, threatening the nascent recovery of the world economy from the severe global financial crisis of 2008-2009. The financial crisis of subprime mortgages began in the United States in 2006. The assumptions of the crisis date back to 2003, when it began to significantly increase the disbursement of high-risk mortgages, ie to customers who would not have obtained credit under normal conditions. since they would not have been able to provide sufficient guarantees. The factors that have stimulated the growth of subprime mortgages are attributable, inter alia, to the dynamics of the US real estate market and the development of securitization (Velte, P., \& Eulerich, M. (2014)).

From 2000 until mid-2006, house prices in the United States have grown steadily and significantly, generating a real housing bubble. This dynamic was favored by the accommodating monetary policy of the Federal 
Reserve (FED), which maintained interest rates on historically low values until 2004, in response to the internet bubble crisis and the September 11, 2001 attack.

Monetary policy. Low interest rates amounted to a low cost of money for borrowers of funds, ie for households that required mortgage loans, and therefore ended up stimulating the demand for housing, further fueling their prices. Furthermore, the real estate bubble made it convenient for mortgages to be granted by financial institutions which, in the event of insolvency of the borrower, could in any case recover the money lent through the attachment and resale of the home.

Securitization. In addition to the housing bubble and low interest rates, the growth of subprime mortgages was also supported by the development of securitization transactions, ie the possibility for banks to transfer mortgages, after having 'transformed' them into a security, to subjects third parties (the so-called 'vehicle companies') and to immediately recover a large part of the credit that would otherwise have been collected only at the end of the loans themselves $(10,20$ or 30 years later). The securitization allowed the banks, apparently, to get rid of the risk of insolvency of the borrowers of the funds and thus weakened the incentive to correctly assess the reliability of the customers. The vehicle companies, for their part, financed the purchase of securitized loans by offering short-term securities to investors.

The special purpose vehicle (SPV) and conduit companies included medium and long-term loans sold by banks and short-term securities (the so-called Asset backed commercial paper - ABCP), guaranteed by the transferred banking assets and assisted by lines of liquidity made available by the banks themselves. An alternative form of securitization envisaged the issuance of the so-called Collateralised Debt Obligations (CDO) again through special vehicle companies (often also designated under the name CDO) and resecuritization operations, in which the underlying assets were mainly structured securities (El Nashar, T. (2016)).

In a context of low interest rates, securitized securities have been subscribed by many investors both in the US and in Europe. This circumstance has created the conditions for the transmission of the crisis from the US economy to the European economies Krauß, P., \& Zülch, H. (2013).

The expansion of leverage. The development of the securitizations has led to the transition of the banking business model from the original approach and hold (the bank pays the loan and waits a period of time before recovering the sum lent and related interests) to the approach originated and distribute (the bank issues the loan and transfers it to third parties through securitization, immediately recovering the sum loaned). As a result of the securitization, the banks quickly fell in the availability of the money lent, which could be reused to provide other loans to customers whose reliability was evaluated in an increasingly less accurate. Thanks to the securitization, financial institutions could greatly expand their assets in relation to their capital (a phenomenon of leverage or financial leverage). This allowed them to make very high profits, but also exposed them to the risk of huge losses (Velte, P., \& Eulerich, M. (2014).

The role of rating agencies. The securitization transactions generated very complex structured products, not standardized and not very liquid. In addition, structured products were traded mainly over the counter (OTC), ie outside regulated markets, and in the absence of significant prices, ie prices that could be used for their assessment shared by market participants. In this context, given the opacity of products and the difficulty of appreciating their value, the rating agencies' judgment has assumed increasing importance as a shared reference for the evaluation Velte, P. \& Stiglbauer, M. (2012).

3. First Part: International Financial Markets Risks and the necessity for a Reregulation. To day we may be convinced of the importance the main risks of the Financial Market that they can be defined in "Foreign exchange and political risks", "Market Imperfections", and "Expanded opportunity set". As well we see, these major dimensions of international finance largely stem from the fact that sovereign nations have the right and power to re-regulate in terms of issue currencies, formulate their own economic policies, impose taxes, and regulate movements of people, goods, and across their borders. When firms and individuals are engaged in cross border transactions, they are potentially exposed to Foreign Exchange Risk that they would normally encounter in purely domestic transactions. Currently the exchange rates among such major currencies as the U.S. Dollar, Japanese Yen, British Pound, and Euro fluctuate continuously in an "unpredictable manner". This has been the case since the early 1970s, when fixed exchange rates were abandoned. Exchange rate uncertainty will have a pervasive influence on all the major economic functions, including consumption, production, and investment. Another risk that firms and individuals may encounter in international setting is 
Political Risk. Political Risk ranges from unexpected changes in tax rules to outright expropriation of assets held by foreigners. Political risks arise from the fact that a sovereign country can change the "rules of the game" and the affected parties may not have effective recourse (Feten, A., \& Salma, D.-A. (2015). In 1992, the Enron Development Corporation, a subsidiary of a Huston-based energy company, signed a contract to build India's largest plant. After Enron has spent nearly $\$ 300$ million, the project was canceled in 1995 by nationalist politicians in the Maharashtra state who argued India did not need the power plant. The Enron episode presents the difficulty of enforcing contracts regulation in foreign countries. Multinational firms and Investors should be particularly aware of political risk when they invest in those countries without a tradition of the rule of law and It is important to understand that the property rights of shareholders and investor are not universally respected and the consequent necessity of a international reregulation. Although the world economy is much more integrated today than was the case of 20 years ago, a variety of barriers still hamper free movements of people, goods, and services, and capital across national boundaries. These barriers include legal restrictions, excessive transaction and transportations costs, information asymmetry, and discriminatory taxation. The world markets are thus highly imperfect. Market Imperfections, which represent various frictions and impediments preventing markets from functioning perfectly, play an important role in motivating MFNCs to locate production overseas. Honda, a Japanese automobile company, for instance, decided to establish production facilities in the United States, mainly to circumvent trade barriers. One might even say that MFNCs are a gift of market imperfections. Imperfections in the world financial markets tend to restrict the extent to which investors can diversify their portfolios. An interesting example is provided by Nestle' Corporation, a well-know Swiss MNC. Nestle' used to issue two different classes of common stock, bearer shares and registered shares, and foreigners were allowed to hold only bearer shares. Additionally when firms venture into the arena of global markets, they can benefit from an Expanded Opportunity Set, firms can locate production in any country or region of the world to maximize their performance and raise funds in any capital market where the cost of capital is the lowest. In addition, firms can gain from greater economies of scale when their tangible and intangible assets are deployed in a global basis. A real world example showing the gains from a global approach to financial management is provided by the following excerpt from The Wall Street Journal (April 9, 1996): "Another factor binding bond markets ever closer is large companies flexibility to issue bonds around the word at will, thanks to the global swap market. At the vanguard are companies such as General Electric of the U.S. Mark VanderGried, who runs the financing desk at Banque Paribas, says it took about 15 minutes a four billion franc (\$791.6 million) deal for GE. By rising the money in francs and swapping into the dollars instantly, GE will save five hundredths of percentage point or about $\$ 400,000$ annually on the nine-year deal". Individual investors can benefit greatly if they invest internationally rather than domestically this increase the probability of Moral Hazard with the consequence of a necessary Reregulation to day in the financial Market (Jacqueline L. Doyle, J. Colley, and W. Stettinius 2013).

4 The Reregulation and the Reorganization of the International Financial Management. The effective Reregulation of the International Financial Management, however is more than the application of the newest business and financial techniques or operating more efficiently (Ferri Di Fabrizio, L. (2017). There must be that the fundamental goal of the Financial Management to day is shareholder wealth maximization reducing the probability of a future financial crisis. Shareholders Wealth Maximization means that the firms makes all business decisions and investments with an eye toward making the owners of the firm - the shareholders - better off financially, or more wealthy, than they were before. Whereas shareholder wealth maximization is generally accepted as the ultimate goal of financial management in "Anglo-Saxon" countries, such as Australia, Canada the United Kingdom, and especially the United States, it is not widely as widely embraced a goal in the other parts of the world. In countries like France, Italy and Germany, for example shareholders are generally viewed as one of the "Stakeholders of the firms", others being employees, customers and supplies, banks and so forth (Murase, H., Numata, S., \& Takeda, F. (2013)). European Managers tend to consider the promotion of the firm's stakeholders overall welfare as the most important corporate goal. In Japan, on the other hand, many companies form a small number of interlocking business groups called Keiretsu, such as Mitsubishi which arose from consolidation of family-owned business empires. It is pointed out, however, that has capital markets are becoming liberalized and internationally integrated in recent years, even managers in recent years in Italy, France, Japan and Germany and other non-Aglo Saxon countries with this kind of reregulation are beginning to pay serious attention to shareholder wealth maximization. Obviously, the financial firm could pursue other goal. This not means, however, that the goal of shareholder wealth maximization is merely an alternative. If the financial firm seeks to maximize shareholder wealth, it will most likely simultaneously be accomplishing other legitimate goals that are perceived worldwide. 
Shareholder wealth maximization is a long-run goal (Minow N., Robert A.,(2015). A firm cannot stay in a business to maximize shareholder wealth if it threats employees poorly, produces shoddy merchandise, wastes raw materials and natural resources, operates inefficiently, or fails to satisfy customers. Only a well-managed business firm that profitably produces what is demanded in a efficient manner can expect to stay in business in the long run and thereby provide employment opportunities this only if the firm or financial company provides a huge supervision over its operation detecting risks, that we have previously mentioned, and taking appropriate actions. While managers are hired to run the financial company for the interest of the shareholders, there is no guarantee that they will actually do so. As shown by a series of recent corporate scandals at companies like Enron, WordCom, and Global Crossing where managers may pursue their own interest at the expense of the shareholders when they are not closely monitored. This so-called Agency Problem is a major weakness of the public corporation. Using an evident amount of resources addressed by companies for supervision the possibility of malfeasance and accounting manipulations at these companies decreases avoiding financial distress and bankruptcy and preventing devastation of shareholders and employees. Some senior managers are monitored and controlled by the possibility to enriched themselves enormously in the process. Clearly, the board of directors has to perform his duty inside of the financial company (Habbash, M. (2012). In presence of these enforcements of corporate regulations the credibility in the free market system increases. After these scandals the society has painfully learned the importance of corporate governance, that is, the new financial and legal framework for regulating the relationship between company's management and its shareholders. This policy not only have a positive effect inside of United States and Europe but also in the emerging economies as Indonesia, Korea, China, and Russia where the legal protection of shareholders is weak or virtually non-existent (Kandemir, H. K. (2016)). The Reconstruction of the organization of the financial firms is necessary where the Corporate Governance structure varies greatly across countries, reflecting different cultural, legal, economic, and political environment in different countries. Precisely in the countries where the shareholders do not have strong legal rights, and corporate ownership tends to be concentrated, the ownership may give rise to the conflicts of interest between dominant shareholders (often the founding family) and small outside shareholders. The collapse of Parmalat, a familycontrolled Italian company, after decade of accounting frauds, provides an introduction of a reregulation of the organizational structure preventing ex-ante moral hazards and distortionary incentives from the owners and ex-post reducing tax in case of failure. "The Government has to be present regulating giving a strong sense of state, public and social services. The owner families are less incentives to operate through moral hazard in presence of efficient institutions". A new regulation based on Shareholders as owner of the business, it is their capital that is at risk. It is only equitable that they receive a fair returns on their investment (Eun, Resnick and Sabherwal, 2004).

Conclusions: Economic Consequence, Costs and Benefits of the Reregulation of the Financial Sector. The Macro and Micro effects of the Reregulation and Reorganization of the Financial Sector, that we resume in "Regulation for the Supervision of the Financial Firms and Markets more efficient", "Allocation of Resources for putting Supervisors in a position to detect better the Risks of the International Financial Market" and "Reorganization of the Financial Firms for prevent Moral Hazard and Agency Problems' behaviors by the Owners", are different and heterogeneous (Wilkinson, N., \& Coetzee, P. (2015). Primary, the Regulation for the Supervision has economic consequences defined in major control of the Financial activities to the services of the shareholders with the object of the Shareholders Wealth Maximization, more transparency, and guarantee of shareholder's rights. The costs for the Central Banks as European Central Bank and Federal Reserve is to reduce their direct control to the Financial firms delegating the power to the Supervisors. Consequently, the reduction of the services offered by the banks and others intermediaries with the aims to avoid the development of the Moral Hazard' behavior by the Owners, the reduction of the organizational profit, and the reduction of the probability of a future financial crisis with e estimated loss grater than the loss of the previous financial crisis estimated in $\$ 15$ Trillions are benefits (Ledimo, O., \& Martins, N. (2014)). Secondly, the Macroeconomic impact on credit supply and the economic growth of the Allocation of Resources for Supervisors is defined in a efficient allocation of the resources available, loss minimization and the reduction of the illicit appropriation of the firm's revenues. This has the effect on a increment of the amount of money putted in the international financial market as monetary policy or the Keynes effect, necessary for improve the acceleration the economy process $(K r a u \beta, P ., \&$ Zülch, H. (2013)). Other benefits can be major revenues of firms in a well-managed business in a long run goal with a major customer loyalty. In particular, the costs are less profits of the firms in presence of a huge amount of resources allocated to supervisions and the possibility of arbitrage between countries and types of financial firms for non - 
controlling financial activities and permitting illegal and Moral Hazard actions to operate. Third, the Reorganization of the Financial Firms it involves at last the economics consequences of the reduction of Agency Problems, as previously defined, in the Financial Firms with a concentrated ownership (Italian family financial company) and major dynamicity of the Multinational Financial Companies that operate in different heterogeneous countries preventing the Financial Market Risks (Foreign exchange and political risks, Market Imperfections, and Expanded opportunity Set). The relevant effect on the size of the financial sector, on profits and salaries to be expected in the future are a major protection and extension of the rights for shareholders respecting the ownership that owns a major share concentration (R. I. Tricker 2017).

\section{References}

\section{Books}

1. Ian P., Tricker S. (2017). Corporate Governance: Principles, Policies, and Practices. Mac Graw Hill, New York, U.S.A. Available at: https://www.researchgate.net/publication/ 283578710_Corporate_ governance_and_accountability_of_state-owned_enterprises_Relevance_for_science_and_society_and interdisciplinary_research_perspectives

2. Minow N., Robert A. (2015). Corporate Governance. Whiley, New York, U.S.A. Available at: https://www.wiley.com/en-us/Corporate+Governance\%2C+5th+Edition-p-9780470972595

3. Resnick E., Sabherwal S. (2004). International Finance. Mac Graw Hill, New York, U.S.A. Available at: https://pdfrog.com/download/international_financial_management_eun_resnick_6th_edition.pdf

4. Velte, P. \& Stiglbauer, M. (2012). Impact of auditor and audit firm rotation on accounting and audit quality: A critical analysis of the EC regulation draft. Journal of Governance and Regulation, 1(3), 7-13. http://doi.org/10.22495/jgr_v1_i3_p1

5. Wilkinson, N., \& Coetzee, P. (2015). Internal audit assurance or consulting services rendered on governance: How does one decide? Journal of Governance and Regulation, 4(1-2), 186-200. http://doi.org/10.22495/jgr v4 i1 c2 p3

6. Feten, A., \& Salma, D.-A. (2015). The use of international standards in ethics education in the Tunisian audit context. Journal of Governance and Regulation, 4(4-4), 499-506. http://doi.org/10.22495/jgr_v4_i4 c4 p p7

7. Indonesia Corporate Governance Manual. (2014). First Edition Jakarta January 2014.

\section{Jounals}

1. Alrabba, H. M. (2016). Measuring the impact of code of ethics on the quality of auditors' professional judgment. Journal of Governance and Regulation, 5(4), 54-60. http://doi.org/10.22495/jgr_v5 i4 p4

2. El Nashar, T. (2016). The probable effect of integrated reporting on audit quality. Journal of Governance and Regulation, 5(2), 50-58. http://doi.org/10.22495/jgr_v5_i2_p6

3. Habbash, M. (2012). Earnings management, audit committee effectiveness and the role of blockholders ownership: Evidence from UK large firms. Journal of Governance and Regulation, 1(4-1), 100-116. http://doi.org/10.22495/jgr v1 i4 c1_p1

4. Kandemir, H. K. (2016). Auditing versus consultancy: a critique of the EU law reforms on the new form of auditing. Journal of Governance and Regulation, 5(3), 90-97. http://doi.org/10.22495/jgr_v5 i3 p8

5. Krauß, P., \& Zülch, H. (2013). The relation of auditor tenure to audit quality: Empirical evidence from the German audit market. Journal of Governance and Regulation, 2(3), 27-43. http://doi.org/10.22495/jgr_v2_i3 p2

6. Ferri Di Fabrizio, L. (2017). The pattern of fraudulent accounting: Ethics, external auditing and internal whistle-blowing process. Journal of Governance and Regulation, 6(1), 12-25. http://doi.org/10.22495/jgr_v6_i1_p2

7. Ledimo, O., \& Martins, N. (2014). An audit of employee commitment to enable leaders to manage organisational talent. Journal of Governance and Regulation, 3(3-1), 128-133. http://doi.org/10.22495/jgr_v3_i3_c1_p6

8. Murase, H., Numata, S., \& Takeda, F. (2013). [Conference issue]. Journal of Governance and Regulation, 2(3), 7-23. http://doi.org/10.22495/jgr_v2 i3_p1

9. Velte, P., \& Eulerich, M. (2014). Increased auditor independence by external rotation and separating audit and non audit duties? A note on the European audit regulation. Journal of Governance and Regulation, 3(2), 53-62. http://doi.org/10.22495/jgr_v3_i2_p5 